\title{
Tomorrow a New World:
}

THE NEW DEAL COMMUNITY PROGRAM

\author{
Ar \\ By Paul K. Conkin
}

PUBLISHED FOR THE

American Historical Association

CORNELL UNIVERSITY PRESS

ITHACA, NEW YORK 


\section{TOMORROW A NEW WORLD:}

The New Deal Community Program 


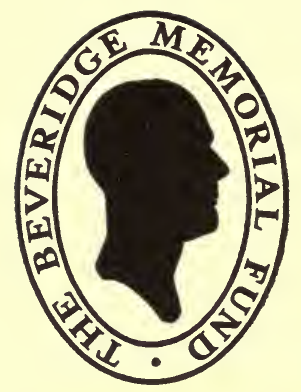

Published under the direction of the American Historical Association from the income of the Albert J. Beveridge Memorial Fund.

For their zeal and beneficence in creating this fund the Association is indebted to many citizens of Indiana who desired to honor in this way the memory of a statesman and historian. 


\title{
Tomorrow a New World:
}

THE NEW DEAL COMMUNITY PROGRAM

\author{
Ak \\ By Paul K. Conkin
}

PUBLISHED FOR THE

American Historical Association

CORNELL UNIVERSITY PRESS

ITHACA, NEW YORK 
(C) 1959 by the American Historical Association

All rights reserved, including the right to reproduce this book, or portions thereof, in any form.

\section{CORNELL UNIVERSITY PRESS}

First published 1959

PRINTED IN THE UNITED STATES OF AMERICA BY THE VAIL-BALLOU PRESS, INC., BINGHAMTON, NEW YORK 